\title{
SCHOLARLY TRANSLATORS AND COMMITTED DISPUTANTS: THE FIRST CENTURY OF THE HUNGARIAN BIBLE
}

\author{
EDINA ZVARA \\ University of Szeged \\ zedina@hung.u-szeged.hu
}

\begin{abstract}
The importance of the early translations, copied or printed, derived from a parallel process that fostered the development of a standard version of the Hungarian language and the norms of literary Hungarian. In Hungary Benedek Komjáti, Gábor Pesti and János Sylvester fulfilled the Erasmus program of translating and distributing the Hungarian translations of the Holy Scriptures. They knew that to achieve this they had to find the appropriate linguistic form. Therefore, they wrote also pieces in different genres and did prepare Bible translations only. Due to the changes brought about by Reformation people needed new books in the vernacular in all areas of life, for example school books, catechisms, church constitution (Kirchenordnung) and of course the Bible. In the century of the Reformation, the Hungarian Protestant ministers who knew languages followed Erasmus' example and felt their duty to translate the Holy Scriptures into Hungarian. at the end of the century the first complete Bible in Hungarian was published in Vizsoly in 1590, which was prepared by a circle of scholars. The first complete Catholic Bible translation was published in 1626 in Viennna thanks partly to György Káldi and partly to Péter Pázmány.
\end{abstract}

Keywords: Bible, Hungarian, Translation, Book History, Reading, Manuscript, Erasmus, János Sylvester, Ptotestantism

During medieval times in Hungary those who wanted to learn to read and write did so in Latin. Reading and writing were separated from Latin in the 15th century. Until then there had been no need for a Bible written in the vernacular. ${ }^{1}$ A small part of society knew the entire Holy Scriptures or at least parts of the Bible from oral tradition. A translation recorded in writing became more important than oral translation only when a new need on the part of the readers emerged for the vernacular. The importance of the early translations, copied or printed, derived from a parallel process that fostered the development of a standard version of the Hungarian language and the norms of literary Hungarian.

Vernacular languages spread and became more dominant than Latin everywhere, even in the Hungarian and the Polish Kingdoms where Latin served as the official language in public affairs until the 19th century. This was due to sev- 
eral reasons. As urbanization was spreading, the vernacular became the language in which daily economic and legal affairs were recorded as the need emerged. Later it became a tool to strengthen one's daily religious practice. Both secular and religious officials keen on keeping their power became interested in enriching the vernacular and forming a standard language that was a tool to keep together the community culturally and society as a whole. Its value, however, was ambiguous for the church since the emergence of the vernacular acted against the universality of the church. Secular power, on the other hand, gave it constant support: this, alongside the feudal vassal power structure, became an organizational force in society, which also counterbalanced and diminished the influence of the church.

The Humanists' interest in linguistics and philology, which constituted the core of Humanism, raised the question: was mother tongue capable of expressing the contents of the Bible? To create the vocabulary and the terminology of Biblical philology in the vernacular posed a serious challenge to Humanist scholars in a period when questions were raised concerning the confessio and the established canons of the church expressing thus a critique of the church itself. New thoughts about religion left their marks also on the translations of the Holy Scriptures. The Roman Catholic Church confronted this problem on the scientific plane, in its church organization as well as politically. The long Council of Trent announced principles based on which no Bible in the vernacular could have been prepared unless politics made it necessary. In the Hungarian Kingdom, for example, if Rome did not want the faithful Catholics to read the Bible translations made by the Protestants they were forced to approve the publication of the Catholic version of the Holy Scriptures, which had already, been prepared. On the other hand, no Protestants lived within the territory formerly known as Croatian Kingdom that then was a part of the Hungarian Kingdom. Therefore, the Croatian translation prepared by Bartol Kasić SJ. the same time as was the Hungarian one could only come out in 2000 as curiosity in philology and not when it was written.

\section{The Bible in Hungarian in the Manuscripts Period}

The history of translations of the Bible started in the 15th century when the literature in the vernacular emerged in the monasteries or convents and when the religious orders committed themselves to perform internal reforms. Behind all this was a special spiritual movement called devotio moderna. The majority of the codices (42 in all) in Hungarian are from the period between 1470 and 1530, a significant part of these are re-translations. Based on the known copies we can assume that there were two or three hundred codices in Hungarian that no longer exist. $^{2}$ Their importance derived from the effort made by the translators to create 
a literary language in Hungarian, which allowed those who did not know Latin to read and write in the vernacular. ${ }^{3}$

Most of these relics are heterogeneous concerning their contents. As far as their genres are concerned, biblical readings figure high on the list. No full Hungarian translation is known from this period, only translated excerpts. The Hussite Bible ${ }^{4}$ of doubtful origin written in the first third of the 15th century contained bigger sections of the Bible and was our first Bible translation. The text survived in three codices (Apor Codex, the Codex of Munich, as well as the Vienna Codex). A partial translation of the Bible was the Jordánszky Codex (1516-1519) which included some of the books of the Old Testament and almost the whole New Testament. ${ }^{5}$ András Nyújtódi, a Franciscan friar from Transylvania translated the Book of Judith to his sister Judit who was a Clarissa. The words were preserved in the Codex of Székelyudvarhely (1526). ${ }^{5}$ Nyújtódi was the first translator of the Bible who named himself.

This blooming period of writing codices in Hungarian ended in the 1530s. The codices were scattered and a part of them were destroyed. Many became forgotten for centuries but the words of a few of them became a source for the Bible translators of the 16 th century. ${ }^{6}$

\section{The Bible translations of the Hungarian followers of Erasmus}

Erasmus undoubtedly had a profound influence on the Humanism in Hungary of the 16th century and its followers. ${ }^{7}$ In Hungary Benedek Komjáti, Gábor Pesti and János Sylvester fulfilled the Erasmus program of translating and distributing the Hungarian translations of the Holy Scriptures. They knew that to achieve this they had to find the appropriate linguistic form. Therefore, they wrote also pieces in different genres and did prepare Bible translations only. Their literary oeuvre, which fostered the development of a standard version of the Hungarian in the 16th century, had a decisive influence on the formation of Literary Hungarian language.

This effort fit well into the contemporary intellectual movements since the vernacular became the expression of national identity everywhere in Europe. ${ }^{8}$ The books written by the second generation of Hungarian Erasmus followers were the outcome of their program and this is where they differed from the authors of the Hungarian monasteries or convents. ${ }^{9}$ Komjáti, Pesti and Sylvester intended to create the literary Hungarian language developed based on Humanist principles. To be able to do this, first they had to study the language itself so that they could make it suitable grammatically and rhetorically for the translation of the Holy Scriptures ${ }^{10}$. This way they could fulfill the noble project to render the "ornate" text in a vernacular but "ornate" language. ${ }^{11}$ When doing the translations, 
the scientific study of the Bible carried out by their intellectual father figure, Erasmus was an immense help for them ${ }^{12}$ although they also used the Vulgata.

The first steps to develop the Hungarian lingua vulgaris was taken by Benedek Komjáti (died after 1533) ${ }^{13}$ when he translated the Epistles of Saint Paul into Hungarian. This book was published outside of the Hungarian Kingdom in Cracow in $1533^{14}$. It is a significant book in book history and in the history of printing since this is the very first book printed exclusively in Hungarian. This book has a symbolic relevance in Hungarian cultural history since it was the beginning of Hungarian literature of a higher rhetoric quality that was aimed at broader strata of Hungarian society. ${ }^{15}$

Gábor Pesti (born around 1510 and died after 1546) was in a good relationship with the professors of the University of Vienna who were the disciples of Erasmus and who opposed Luther. Three books are known by Gábor Pesti. They are the perfect embodiment of his linguistic and literary program and prove him a deserving Erasmus disciple. His Aesope's Fables came out in Vienna in $1536^{16}$, his dictionary of six languages was published also in Vienna in $15388^{17}$ His major objective was to translate the Holy Scriptures into Hungarian. ${ }^{18}$ His Four Testaments came out in Vienna also in 1536. In his preface written in Latin, he referred to Erasmus and quoted him when he was talking about the importance of the Bible translations in the vernacular and about the program for everyone to read the Bible.

János Sylvester (born around 1504 - died after 1552): Beside his Bible translation, he is also known for several other books. He considered his Hungarian Grammar (Sárvár-Újsziget, 1539) as a preliminary study for the great mission he had. His translation of the New Testament (Sárvár-Újsziget, 1541) ${ }^{19}$ is one of the most important works of the Hungarian Erasmists and a milestone in Hungarian intellectual history. This is the first complete New Testament in Hungarian and the first print in Hungarian published in Hungary.

Sylvester, the disciple of the Erasmist Leonard Cox wanted to translate the original words of the Bible into Hungarian in the most precise way keeping in mind the Bible critical principles of Erasmus. He did this because, as he wrote in his preface, most of the Hungarians did not speak any other languages. He was following in the footsteps of the Humanist from the Low Countries when he applied the ad fontes principle in his work: he had all the necessary skills to do this. He knew grammar, he was well versed in all the sacred languages and he connected this knowledge with a programme to foster his mother tongue. At the end of this work, Sylvester realized that it was possible to write poems in Antiques metres in Hungarian. His best distich, which comes right at the beginning of his New Testament, is, in fact, a brief summary of the teachings of Erasmus.

When translating the Bible, Sylvester had the books of Erasmus, the Vulgata at his disposition. His monographer believes Sylvester knew Martin Luther's Ger- 
man New Testament translation as well. ${ }^{20}$ This latter is important especially because, like Komjáti or Pesti or their intellectual mentor, Erasmus, he never joined Reformation and stayed a Catholic all through his life. For Komjáti or Pesti the idea to embrace Protestantism never occurred. As for János Sylvester, especially Protestant church historians and literary historians wondered about the possibility of Sylvester being Protestant due to several factors: he studied in Wittenberg where his mentor was Philipp Melanchthon (1497-1560) as was customary for Hungarian students then. Sylvester called Melanchton "praeceptor noster"21 in his grammar. The fact that in one of his letters Sylvester called the pope "sanctissimus Pater"'22 refers to his being a Catholic. If he had been a committed follower of the Reformation, he would never have written something like that. His being Catholic is even more reinforced by what the publisher emphasized in the preface to the second edition (Vienna, 1574) of his New Testament that it was going to "strengthen the orthodox faith", which meant Catholicism in contemporary terminology..$^{23}$

Hungarian philologists studied Sylvester's books many times, the examples he gave in his grammar and the sources of his Bible translations. In his grammar, one can state that he used Erasmus' books ${ }^{24}$ while in his Bible translations one is not so sure. A new philological study of his New Testament may yield new results. Let me draw your attention to the translation of Matthew III, section 2. ${ }^{25}$ When reading the contemporary translations (e.g. by Sebastian Münster, Jacques Lefèbvre d'Étaples, Pierre Robert Olivétan) one cannot help but notice that Sylvester used the New Testament translated not by Erasmus ${ }^{26}$ but by Martin Luther. ${ }^{27}$ He did not write "convert" but "Consider yourself and better your life because the Lord's kingdom is coming". ${ }^{28}$ Conversion should not just happen in deeds but also in the head and in thoughts.

As a summary, we can say that we cannot consider János Sylvester a Protestant but the influence of Reformation is the strongest in his oeuvre. ${ }^{29}$ This is not surprising since he lived in times of transition when several of the Humanist scholars were torn by "spiritual and intellectual inner fights." 30

\section{Hungarian Bible Translations in the spirit of Protestantism}

Due to the changes brought about by Reformation people needed new books in the vernacular in all areas of life, for example school books, catechisms, church constitution (Kirchenordnung) and of course the Bible. In the century of the Reformation, the Hungarian Protestant ministers who knew languages followed Erasmus' example and felt their duty to translate the Holy Scriptures into Hungarian. The influence made by Erasmus, the outstanding Humanist on the early Hungarian Bible translations is clear, as many studies have pointed out. This influence 
is also reflected in the prefaces to these published translations. These prefaces can all be read in one book. ${ }^{31}$ Three characteristics can be traced in them: the philological erudition of the translators, their interest in their own mother tongue from the point of view of the philosophy of language and grammar and a thorough knowledge of early Protestant teachings. ${ }^{32}$

Among the Protestants, István Bencédi Székely (born after 1500 - died after 1563) made the first attempt to translate the psalms in prose (published in Cracow, 1548). ${ }^{33}$ In the first part he used the original Hebrew as well as Latin and medieval Hungarian translations. However, the second part proves his knowledge of the Hebrew language, which he must have learnt during his studies in Cracow. ${ }^{34}$ When translating the second part of the psalms, he used the commentaries of the most renowned rabbis. From his preface, we know that he planned to translate the whole Bible. ${ }^{35}$ He never did.

In Kolozsvár, a town in Transylvania (Cluj-Napoca, Klausenburg, today is in Romania), an important printing house operated at the middle of the 16th century. Gáspár Heltai (1510-1574) was the director of the operation as well as the intellectual leader of his circle. They aimed at translating the whole Bible into Hungarian. Although they did not manage to complete the full scope of this work, due to their work, between 1551 and 1565 seven books were published. ${ }^{36}$ In their scholarly circle, the distribution of the work was done according to the language skills and the discipline areas of their members. Heltai himself wrote about this in one of his prefaces. ${ }^{37}$ The translators justified their work by stating the following: "We need the Bible in Hungarian because there are very few among the Hungarians who know Latin sufficiently to understand the Bible just literally." ${ }^{38}$

Within the Hungarian Kingdom, in Debrecen two Protestant ministers made Bible translations. One of them was Péter Melius Juhász (1532-1572), the famous preacher. He prepared several translations of which only two survived. ${ }^{39}$ Melius Juhász joined those who considered it their duty to translate the entire Bible because few people understood Latin and because it was God's will for a minister to preach to his community in their mother tongue. ${ }^{40} \mathrm{He}$ named his sources: the original Hebrew texts, Franciscus Vatablus, Sebastian Münster, and a Bible translation prepared by Jean Calvin and his colleagues that was published in Geneva in $1535 .{ }^{41}$ Melius Juhász also used Erasmus' Latin translation and he even referred to it in his book of sermon.

The other Bible translator from Debrecen was Tamás Félegyházi (born around 1540-1586) who translated the New Testament ${ }^{42}$ into Hungarian (1586). After his death, his work was completed by his colleague, Minister György Gönczi.

Finally, at the end of the century the first complete Bible in Hungarian was published in Vizsoly in $1590,{ }^{43}$ which was prepared by a circle of scholars similarly to the ones that came out in Kolozsvár. The publication of the great book 
was belated sine by the time it was printed the Holy Scriptures had been out in German, Italian, Catalan, Czech, Polish and English language. ${ }^{44}$

Gáspár Károlyi (1529-1591), minister of the Reformed Church in Gönc, organized the translation and the printing. ${ }^{45}$ In his preface written to the Bible, he argued for the regular use and reading of the vernacular Holy Scriptures and spoke also about reading them at home. He criticized the Catholics who banned all these. He also found faults with the "old Bible", the Vulgata and enumerated its mistakes. Károlyi also wrote about the methods and the sources they used during the translation. He named Franciscus Vatablus, Sebastian Münster, Santes Pagninus és Immanule Tremellius as sources.

\section{Catholic Bible Translations}

The first complete Catholic Bible translation was published quite late in 1626 in Viennna thanks partly to the Jesuit priest, György Káldi (1573-1634) who made the translation and partly to the most influential Hungarian theologist, Péter Pázmány (1570-1637), Archbishop of Esztergom (who was also a Jesuit before becoming a high clergy). Both remarks need to be justified. It is unclear whether Káldi used the manuscript translation of his confratello István Szántó Arator (1541-1612) for his translation. Szántó Arator's rendition had never been published and the manuscript disappeared. ${ }^{46}$

The Roman Inquisition allowed the publication and reading of the Catholic Bible translations to different degrees and for varying reasons. Their experts thought that prohibiting this in areas where the population was of mixed faith had no sense. ${ }^{47}$ Despite all this, the translation of the Croatian Bartol Kašić (15751650) was not allowed to be published ${ }^{48}$ while the Hungarian Péter Pázmány managed to publish a Catholic Bible translation.

György Káldi wrote a treatise for his Bible translation instead of a preface. Beyond issues of theology, church history and dogma, he argued that the Roman Catholic Church did not prohibit the translation of the Holy Scriptures into the vernacular. He also mentioned that it was not always advisable to read the Bible in the vernacular since the lack of learning and ignorance could mislead the believer. He also attacked the protestant Bible translations especially the Károlyi Bible, pointing out its weaknesses. Káldi claimed that the Protestant Bible translators made up a new Bible. He stated that Károlyi's criticism of the Catholics for the Latin Bible was ungrounded and made a stand for the authority and authenticity of the Vulgata based on the dogmas accepted at the Council of Trent. The Bible translations were needed, Káldi argued, because Catholics who wanted to read the Bible in their mother tongue should not read the distorted translation made 
by the Protestants. The Káldi-Bible was, in fact, a kind of a reply Pázmány and his followers gave to the Protestant Reformation in the spirit of Catholic renewal.

The importance and the need of reading in someone's mother tongue and the program for everyone to read the Bible was not, as we could see, "invented" by the Protestant Reformation. They had more ancient roots in trends for Catholic renewal (mendicant orders, movements labelled as heretical, devotio moderna) and in part Christian Humanism (Erasmus). Since the Central European region has always been influenced by German culture, ${ }^{49}$ the phenomenon that the Lutheran reformation and the ideas of Humanism affected this region at the same time can be considered natural. Among the Hungarian Bible translators there were several who followed Erasmus' ideas or who studied in Wittenberg, where the vernacular program of the scholars in Wittenberg, especially Melanchton, had a profound influence on them. As a parallel in Central Europe we can point out János Sylvester (1504-1551) discussed above, the Finnish Mikael Agricola $^{50}(1510$ circa -1557$)$ or the Slovenian Primož Trubar (1508-1586). ${ }^{51}$ Both Sylvester and Agricola studied in Wittenberg and both were influenced by the Praeceptor Germaniae. After returning home, Sylvester prepared his Hungarian grammar in 1539 and then completed the first Hungarian New Testament in 1541. Agricola made a book of alphabet before he made his Finnish Bible translation in 1548. Trubar got to know Erasmus' teachings as an adult and was profoundly influenced by the vernacular programme of the scholars in Wittenberg. Most of his books (book of alphabet, catechism and Bible translations) were written in his mother tongue. He published the New Testament first in several parts and then the complete version came out $(1557,1560,1577$, and 1580).

One can also cite examples from the following generation: ${ }^{52}$ The Hungarian Gáspár Károlyi (1529-1591) wrote the first review in Hungarian of the Wittenberg historiography in 1563 and then with his colleagues made the first Hungarian complete Bible translation in 1590. His contemporary, Johannes Bretke $(1536-1602)^{53}$ prepared the first Bible translation in Lithuanian (although his translation remained unpublished) and wrote history books.

The "everyone reads the Bible" program was handed down in the $16^{\text {th }}$ century Hungary ${ }^{54}$ from generation to generation and from one intellectual trend to the other as was explained by almost all translators in their prefaces to their Bible translations. The champions of the Reformation in Hungary did a lot to achieve this, but the realization came only in later periods. ${ }^{55}$ 


\section{Notes}

1 Edit Madas, "Középkori bibliafordításainkról (On our Bible translations from Medieval Times)," Iskolakultúra 8/1 (1998): 48-54.

2 Further on this see: Edit Madas, "Codex Literature in Hungarian, (1440-1530)," in Potentates and Corvinas: Anniversary Exhibition of the National Széchényi Library, ed. Orsolya Karsay (Budapest: Országos Széchényi Könyvtár, 2002), 163-169. Edit Madas, "Les ordres mendiants en Hongrie et la littérature médiévale en langue vérnaculaire (XIIIe-XVe siècle)," in Entre stabilité et itinérance: Livre et culture des ordres mendiants, ed. Nicole Bériou, Martin Morard, Donatella Nebbiai (Turnhout: Brepols, 2014), 367-374. Sándor Lázs, Apácamüveltség Magyarországon a XV-XVI. század fordulóján: Az anyanyelvü irodalom kezdetei (The Education of Nuns in Hungary at the Turn of the 15th and 16th Centuries: The Beginnings of Literature in Hungarian) (Budapest: Balassi, 2016), 190-199. “Látjátok feleim...”: Magyar nyelvemlékek a kezdetektöl a 16. század elejéig: Az Országos Széchényi Könyvtár kiállitása 2009. október 29 - 2010. február 28. (Hungarian linguistic relics from the beginning until the 16th century, an exhibition of the Hungarian National Széchényi Library), ed. Edit Madas (Budapest: OSZK, 2009).

3 Edit Madas, Codex Literature in Hungarian ..., 163-169. (hier: 165.)

4 Scholars defending the Hussite theory this translation was made by Hussite priests for Hungarian followers of Hussitism in Hungary. This question has remained unsolved. Cf. Balázs Kertész, "Bécsi Kódex (Vienna Codex)," in "Látjátok feleim ...", 256-257. Balázs Kertész, "Der Münchener Kodex: ein ungarisches Sprachdenkmal aus dem 15. Jahrhundert," Danubiana Carpathica 2 (2008): 19-30, 310-318. György Galamb, “A Huszita biblia és a ferencesek: Megjegyzések az első magyar bibliafordítás kérdéséhez (The Hussite Bible and the Franciscans: Comments tot he first Hungraian Bible translations)," Egyháztörténeti Szemle 10/2 (2009), 3-12.

$4{ }^{5}$ Pál Ács, Jordánszky-kódex, in “Látjátok feleim...., 264-265.

5 ' Judit Lauf, Székelyudvarhelyi kódex, in “Látjátok feleim ...”, 270-271.

$6{ }^{7}$ Cf. Ildikó Hubert, "Pesti Gábor négy evangéliumfordítása (Four translations by Gábor Pesti)," in Gábor Pesti Mizsér, Új Testamentum magyar nyelven (The New Testament in Hungarian Bécs, 1536), facs. ed. (Budapest: MTA ITI, OSZK, 2002).

$7{ }^{8}$ Pál Ács, "Erasmus and the Hungarian intellectuals of the sixteenth-century," in In search of the republic of letters: intellectual relations between Hungary and the Netherlands 1500-1800, ed. Arnoud Visser (Wassenaar: Study Centre on the Republic of Letters in the Early Modern Period, NIAS, 1999), 21-27. Pál Ács, "Bibles and Books: Bohemia and Hungary," in A Companion to the Reformation in Central Europe, ed. Howard Louthan and Graeme Murdock (Leiden-Boston: Brill Publishers, 2015), 400-411. Ágnes Ritoók-Szalay, Erasmus und die ungarischen Intellektuellen des 16. Jahrhunderts. - In: Buck, August (Hg.): Erasmus und Europa. Wiesbaden: Harrassowitz, 1988 (= Wolfenbütteler Abhandlungen zur Renaissanceforschung 7). S. 111-128. István Bartók, "Erasmus hatása (Erasmus' Influence)," in Magyar Müvelödéstörténeti Lexikon, Vol. 2., ed. Péter Kőszeghy (Budapest: Balassi, 2004), 348-352. István Monok, "The Distribution of Works by Erasmus in the Carpathian Basin during the Sixteenth and Seventeenth Centuries: (Summary of Statistical Spread)," in Republic of Letters, Humanism, Humanities: Selected papers of the workshop held at the Collegium Budapest in cooperation with NIAS between November 25 and 28, 1999, ed. Marcell Sebők (Budapest: Collegium Budapest Institute for Advanced Study, 2005), 35-43.

8 István Bartók, Erasmus hatása (Erasmus'influence)..., 350.

9 Pál Ács, Erasmus and the Hungarian intellectuals..., 24. 
10 Same.

11 Pál Ács, "A magyar irodalmi nyelv két elmélete: az erazmista és a Balassi-követő (Two Theories of the Hungarian Literary Language: The Erasmus theory and the one follwoing Balassi)," in Pál Ács, "Az idö ósága": Történetiség és történetszemlélet a régi magyar irodalomban ("The oldness of time" - Historicism and vision of history in old Hungarian literature)" (Budapest: Osiris, 2001), 19.

12 Erasmus Roterodamus, Novum instrumentum (Basel, Frobenius, 1516); his commentaries of his Bible: Annotationes (Basel, 1519); also to be noted his paraphrases written to the Pauline letters, Paraphrases in omnes epistolas Pauli (Basel, 1521).

13 Pál Ács, "The Reception of Erasmianism in Hungary and the Context of Erasmian Program: The "Cultural Patriotism" of Benedek Komjáti," in Whose Love of Which Country?: Composite States: National Histories and Patriotic Discourses in Early Modern East Central Europe, ed. by Balázs Trencsényi and Márton Zászkaliczky (Leiden: Brill, 2010), 77.

14 Transl. Benedek Komjáti, Epistolae Pauli lingua hungarica donatae: Az Szent Pál levelei magyar nyelven (The Pauline Epistles in Hungarian language) (Krakkó, Hieronymus Vietor, 1533.) New edition: ed. and transcribed, annotated and prefaced by András Mezey, glossary and linguistic preface by Katalin Pelczéder, Béla Kocán, the Latin preface and epilogue was translated by István Dávid Lázár (Budapest: Idea Fontana Kft., Magyarok Nagyasszonya Ferences Rendtartomány, 2013).

15 Pál Ács, The Reception of Erasmianism ..., 75.

16 Transl. Gábor Pesti, Aesopi Phrygis fabulae Gabriele Pannonio Pesthino interprete: Esopus fabulaji, mellijeket mastan wijionnan magijar nijelwre forditot Pesthij Gabriel (Bécs, Singrenius, 1536).

17 Gábor Pesti, Nomenclatura sex linguarum, Latinae, Italicae, Gallicae, Bohemicae, Hungaricae et Germanicae (Wienn, Hans Singriener, 1538).

18 Transl. Gábor Pesti, Novum Testamentum seu quattuor Evangeliorum volumina lingua Hungarica donata, Gabriele Pannonio Pesthino interprete (Viennae Pannoniae, Joannes Singrenius, 1536).

19 Transl. János Sylvester, Új Testamentum magyar nyelven, melyet az görög és diák nyelvböl újonnan forditánk az magyar nipnek keresztyén hütben való ipülisire (The New Testament newly Translated from Greek and Latin for the benefit of the Hungarian people in their Christian faith (Sárvár-Újsziget, Benedek Abádi, 1541).

20 János Balázs, Sylvester János és kora (János Sylvester and his Age) (Budapest: Tankönyvkiadó, 1958), 258.

21 János Sylvester, Grammatica Hungarolatina, in usum puerorum recens scripta Ioanne Pannonio Sylvestro Pannonio autore (Sárvár-Újsziget, 1539), Dij verso: "Philippus Melanchthon praeceptor noster scribens in Grammatica sua Graeca de Graeci sermonis articulis...". It was his paeceptor who recommende sylvester to his future patron, Tamás Nádasdy), János Balázs, Sylvester János és kora (János Sylvester and his Age), 158. Philipp Melanchthon's letter to Tamás Nádasdy, Octobre 1537.

22 “János Sylvester's letter to Ferenc Nádasdy, 29 May 1541," Irodalomtörténeti Közlemények 3/1 (1893): 94-95.

23 István Bartók, “““...a széthúzások pusztító viharában...”: Adalékok Sylvester János Újszövetség-fordításának bécsi kiadásához (“...in the distructive storm of disagreements...”: Remarks to the Viennese edition of János Sylvester' New Testament)," in In via eruditionis: Tanulmányok a 70 éves Imre Mihály tiszteletére (Studies in Honor of the 70th Birthday of Mihály Imre), ed. István Bitskey, István Fazakas, Tamás Gergely, Katalin Luffy, Orsolya Száraz (Debrecen, Debreceni Egyetemi Kiadó, 2016), 102. 
24 István Bartók, Ioannes Sylvester, Grammatica Hungarolatina (Budapest: Akadémiai, Argumentum, 2006). István Bartók, “"Nem egyéb, magyar poézis”: Sylvester János nyelv-és irodalomszemlélete európai és magyar összefüggésekben ("Nothing else but Hungarian poetry": János Sylvester's views on language and literature:in the European and Hungarian context" (Budapest: Universitas, 2007).

25 István Monok drew my attention to this locus.

26 Erasmus Roterodamus, Novum instrumentum (Basel, Johannes Frobenius, 1516), fol. 5.: "Poniteat vos. Appropinquauit enim regnum coelorum."

27 Transl. Martin Luther, Das Newe Testament Deutzsch (Wittenberg, Melchior Lotther, 1522), fol. II. verso: "Bessert euch, das hymel reych ist nach erbey komen." Churchistorian of the Hungarian Lutheran Church, Zoltán Csepregi believes that Sylvester gave Lutheran interpretations at several key points in the New Testament.

28 János Sylvester, Új Testamentum magyar nyelven ..., fol. 5. verso. The other translator, Gábor Pesti followed Erasmus: "Keep penitence."

29 In Protestant historiography there is a long traditon to call Sylvester Lutheran. In the REF500 anniversary year many articles were published on this. The most typical title was the one written by Pál Fónyad where he writes of the New Testament editon of János Sylvester as the first Hungarian Luther Bible. Cf. Bécsi Napló 38/3 (2017): 9.

30 In a somewhat different context see István Monok's "The Occurence of Luther and Melanchton's books in booklists from the early moern periods," In: Müvészet és mesterség: Tisztelgö kötet R. Várkonyi Ágnes emlékére (Art and Profession: A Book in Honor of R. Ágnes Várkonyi), ed. Ildikó Horn and others (Budapest: L'Harmattan, 2016), 131.

31 Humanistes du Bassin des Carpates 1.: Traducteurs et éditeurs de la Bible, ed. István Monok et Edina Zvara avec la collaboration de Eva Mârza (Turnhou: Brepols, 2007).

32 István Monok, "A humanizmus jellegzetességei a Magyar Királyságban és Erdélyben (The Characteristics of Humanism in the Hungarian Kingdom and Transylvania)," in Stephanus noster: Tanulmányok Bartók István 60. születésnapjára: Studies for the 60th Birthday of István Bartók), ed. József Jankovics, Emőke Rita Szilágyi and Márton Zászkaliczky (Budapest: Reciti Kiadó, 2015), 96.

33 Transl. István Székely, Soltar könü Szekely Estuantul magiar nielre fordittatott (Psalteria translated by István Székely into Hungarian language) (Kraków: Lazarz Andrysowic, 1548).

34 Róbert Dán, "Benczédi Székely István Zsoltároskönyvének forrásaihoz," Filológiai Közlöny 13/1-2 (1967): 155.

35 Humanistes du Bassin des Carpates..., 78.

36 Same, 116-173.

37 Same, 124-125.

38 Transl. István Gyulai, A Bibliának elsö része, azaz Mózesnek öt könyve, mely magyar nyelvre fordittatott a régi és igaz szent könyvekböl (Kolozsvár, Heltai, 1551), $\mathrm{c}^{\mathrm{v}}$.

39 Transl. Melius Juhász Péter, Az két Sámuel könyveinek és az két Királyi könyveknek az zsidó nyelvnek igazságából és az igaz és bölcs magyarázók fordításából igazán való forditása magyar nyelvre (Debrecen, 1565). A szent Jób könyvének a zsidó nyelvböl és a bölcs magyarázók forditásából igazán való forditása magyar nyelvre (Várad, 1565).

40 Humanistes du Bassin des Carpates ..., 88.

41 Same, 89-90.

42 Transl. Tamás Félegyházi, Az mi uronk Jézus Krisztusnak Újtestamentoma (The New Testament of our Lord Jesus Christ) (Debrecen, 1586).

43 Transl. Gáspár Károlyi and others, Szent Biblia, azaz Istennek Ó- és Újtestamentumának próféták és apostolok által megíratott szent könyvei: Magyar nyelvre fordittatott egészlen és újonnan az Istennek Magyarországban való anyaszentegyházának épülésére. (The Holy Bible, that is the 
Books of the Old and New Testaments Written by Apostles and Prophets, a complete and new translation, for the benefit of the church in Hungary of our Lord) (Vizsoly, Mantskovits Bálint, 1590).

44 Paul Heinz Vogel, Europäische Bibeldrucke des 15. und 16. Jahrhunderts in den Volksspachen: Ein Beitrag zur Bibliographie des Bibeldrucks (Bade-Baden: Heitz, 1962). Le temps des Réformes et la Bible, dir. Guy Bedouelle, Bernard Roussel (Paris: Beauchesne, 1989). Max Engammare, "Un siècle de publication de la Bible en Europa: la langue des éditions des Textes sacrés (1455-1555)," Histoire et Civilisation du Livre 4 (2008), 47-91.

45 Gáspár Károlyi, the Preacher of Gönc: Selection from the Writings and Documents of Gáspár Károlyi, ed. Szabó András (Budapest: Magvető 1984). András Szabó, A rejtőzködö bibliaforditó (The Bible Translator in Hiding) (Budapest: Kálvin, 2012).

46 From the numerous articles on this see: Antal Molnár, "Le traduzioni cattoliche della Bibbia in lingua croata ed ungherese e l'Inquisizione Romana," in L'eredità classica in Italia e in Ungheria dal Rinascimento al Neoclassicismo, a cura di Péter Sárközy, Vanessa Martore (Budapest: Universitas, 2004), 155-168. A Káldi-biblia kéziratos töredékei (The Fragments of the Manuscipts of the Káldi Bible), introductory study written by Péter Erdö (Budapest: Pytheas, 2015).

47 Antal Molnár, Le traduzioni cattoliche della Bibbia..., 159.

48 István Monok’s review, "Biblia Slavica. Serie IV: Südslavische Bibeln. Band 2,1. Kroatische Bibel des Bartol Kašić. Band 2,2. Kommentare, Wörterverzeichnis. Biblia Sacra. Versio Illyrica selecta, seu declaratio Vulgatae editionis Latinae, Bartholomaei Cassij Curictensis e Societate Jesu Professi, ac Sacerdotis teologi. Ex mandato Sacrae Congregationis de Propaganda Fide. Anno 1625," Histoire et Civilisation du Livre (2005): 359-360.

49 István Monok, "Similarities and differences in the book history of Central Europe in the early modern period: aspects and examples," Hungarian Studies 30/2 (2016): 140.

50 Viljo Tarkiainen, Mikael Agricola (Helsinki: Suomalaisen Kirjallisuuden Seura, 1958).

51 Primus Truber 1508-1586: Der slowenische Reformator und Württemberg, Hg. Sönke Lorenz, Anton Schindling, Wilfried Setzler (Suttgart, W. Kohlhammer Verlag, 2011).

52 István Monok, Similarities and differences..., 141.

53 Lietuviškai Biblijai - 400 metu. Biblijos vertejjas Jonas Bretkūnas: Tarptautinès parodos katalogas $=400$ Jahre litauische Bibel: Bibelübersetzer Johannes Bretke: Katalogs der internationalen Ausstellung, sudarytojos/zusammengest. Ona Aleknavičienė, Jolanta Zabarskaitė (Vilnius: Lietuvos dailès muziejus, 2002).

54 Katalin Péter, “A bibliaolvasás mindenkinek szóló programja Magyarországon a 16. században (The overall program of everyone reading the Bible)," in Katalin Péter, Papok és nemesek: Magyar müvelödéstörténeti tanulmányok a reformációval kezdödö másfél évszázadból (Priests and nobles: Studies on the cultural history of Hungary in the 150-year-long period starting with the Reformation) (Budapest: Ráday Gyüjtemény, 1995), 31-55.

55 Botond Gáborjáni Szabó, "Biblia és olvasás (The Bible and Reading), " in Biblia Sacra Hungarica: "A könyv, mely örök életet ád" ("The book which gives you eternal life"), ed. János Heltai, Botond Gáborjáni Szabó (Budapest: OSZK, 2008), 63-64. 